\title{
Biodiversity and bioprospecting of extremophilic microbiomes for agro- environmental sustainability
}

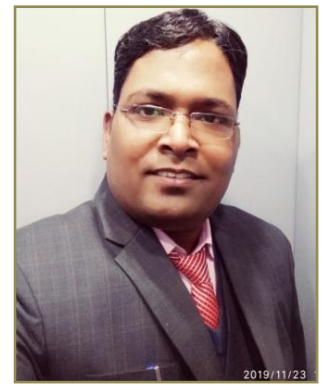

Microbial communities live in a wide variety of environments, including natural normal conditions as well as extreme harsh environmental conditions of temperatures, salinity, water scarcity, and $\mathrm{pH}$. To survive in such conditions, these stress adaptive microbes have developed adaptive properties to survive, multiple and produced bioactive compounds and secondary metabolites under the harsh/extreme conditions [1]. Extremophiles can live in some of the most aggressive environments on the Earth, with salinity (2-5 M NaCl; halophiles), $\mathrm{pH}$ ( $<4$ acidophiles and $>9$; alkaliphiles), temperature $\left(-20^{\circ} \mathrm{C}\right.$ to $20^{\circ} \mathrm{C}$, psychrophiles/ psychrotrophic, $60{ }^{\circ} \mathrm{C}$ to $115{ }^{\circ} \mathrm{C}$; Thermophiles/hyperthermophiles) $[2,3]$. Polyextremophiles have capability to grow optimally under two or more harsh/extreme conditions. True extremophiles are members of archaea, although extremophiles belonging to the domains of bacteria and eukaryotes are also known. Overall, the extremophilic microbiomes belong to different phylum i.e. Euryarcheota, Crenarchaeota, Firmicutes, Proteobacteria Actinobacteria, Deinococcus-Thermus, Bacteroidetes, Basidiomycota, and Ascomycota (Figure 1). These microbial enzymes are of significance for many potential microbial biotechnological applications in, textile industries energy, agriculture, the environment, food industry, healthcare, and pharmaceutical due to the stability and activity of extremozymes under extreme harsh conditions [4-6].

Microbial communities in diverse extreme habitats are physiologically adapted to harsh environmental stresses such as high/low temperatures, salinity/hypersalinity, drought, acidic/ alkalinity, UV radiation and diverse chemical stress [7]. Recently, microbial (archaeal, bacterial and fungal) communities in extreme harsh habitats have paying attention on applications in different areas such as white and green biotechnology, medicine and food production and food processing industry [8]. Extremophiles/ Stress-Adaptive microbes are classified as living microbes that survive or adapt in habitats under the stress conditions such as $\mathrm{pH}$ (acidophilic, alkaline), pressure (piezophiles), radiation (radiation resistance), redox potential

\author{
Ajar Nath Yadav \\ Microbial Biotechnology Laboratory, Department of \\ Biotechnology, Dr. Khem Singh Gill Akal College of Agriculture, \\ Eternal University, Baru Sahib, Sirmour, Himachal Pradesh, India, \\ Email: ajar@eternaluniversity.edu.in; ajarbiotech@gmail.com
}

(xerophiles), salinity (halophiles), and temperature (psychrophilic, thermophilic) $[9,10]$. The polyextremophilic microbiomes have capabilities to survive and growth on two of more stress and harsh environmental conditions.

The beneficial extremophilic microbiomes plays significant role for agro-environmental sustainability as stressadaptive microbes have capability to produce agro-industrially important bioactive compounds such as indole acetic acids, gibberrellic acids, cytokinin, hydrogen cyanides, ammonia, siderophores, 1-aminocyclopropane-1-carboxylate deaminase and extracellular microbial hydrolytic enzymes (amylase, xylanase, pectinase, chitinase, cellulase and have very wide range of applications in different fields such as agriculture, dairy industry, biodegradation, biodegradation production, chemical processing, bioconversion of hemicellulose, molecular biology, composting, detergent industry, food industry, feed additives, feed industry, leather industry, paper and cellulose industry, peptide synthesis, pharmaceutical industry and therapeutic agents [11-13]. Extremophilic microbiomes are use in food and food processing industry as they have capability to produce wide range of bioactive compounds, secondary metabolites and value-added products such as flavors, food ingredients, and vitamins [14, 15].

The biodiversity and distribution of extremophilic microbiomes living in harsh environmental situation has been extensively studied over the past several decades with an emphasis on culturable and metagenomic methods. There are many reports of the microbial biodiversity of extremophilic microbiomes such as xerophiles, halophiles, acidophiles, thermophiles, alkaliphiles, and psychrophiles [16-18]. Microbes from harsh habitats have 


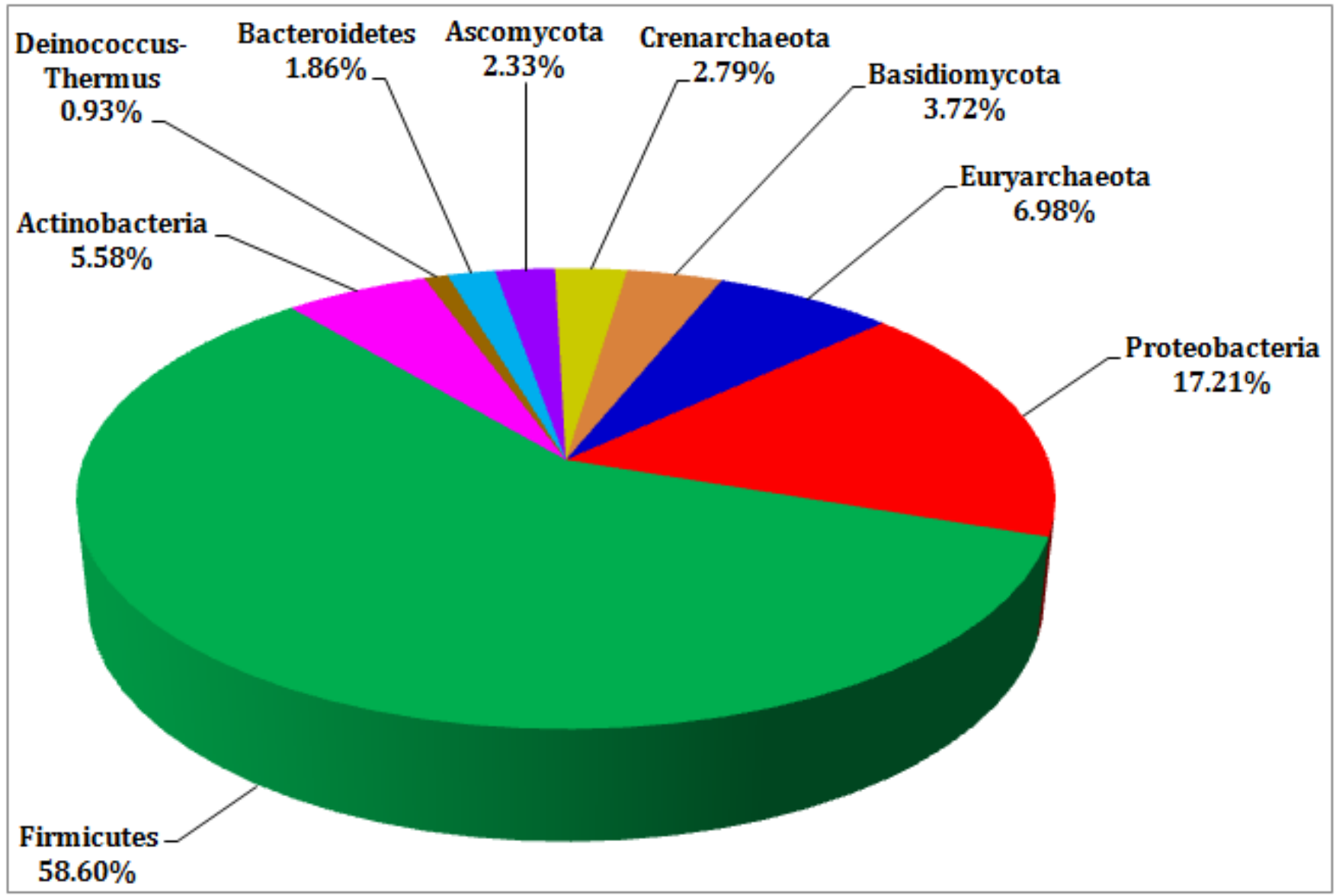

Fig. 1: Extremophilic microbiomes of diverse phylum isolated from a wide range of extreme habitats worldwide. Adapted with permission from Kour, et al. [44].
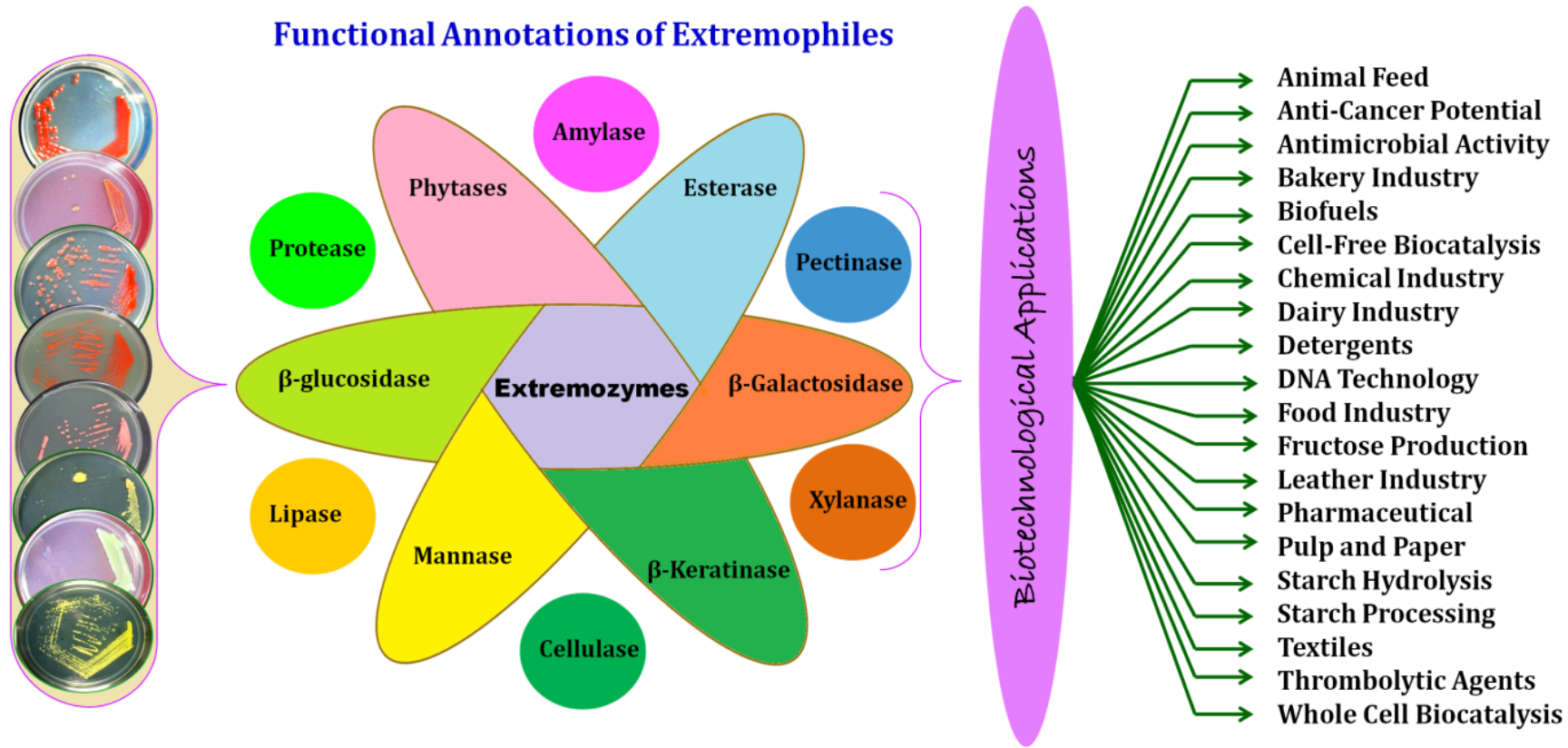

Figure 2: Extremozymes producing microbes and its biotechnological applications. Adapted with permission from Kour, et al. [44] 
potential uses in agriculture, pharmaceuticals and related sectors. Microbial biotechnology of extremophiles may be opens up huge potential for future sustainability. Extremozymes have enormous economic biotechnological potential in many vital biological processes, including agriculture, pharmaceuticals, and chemistry (Figure 2).

Among the extremozymes, amylases are one of the most important microbial hydrolytic enzymes produces by normal as well stress adaptive microbes for all starch-related industries. Enzymes also have great potential in the pharmaceutical and fine chemical industries [19]. Proteases are found in most of reported microbiome, from prokaryotes to eukaryotes and viruses, which are considered one of the commercially important hydrolytic widely used in detergents, food, pharmaceuticals, chemicals, leather and silk industry [20]. They help maintain ecological balance by composition and recycling of agro-waste [21]. Biotechnological refining with pectinases in combination with xylanases offers an environmentally friendly and economical alternative.

Cellulases produced by stress adaptive microbes are currently the $3^{\text {rd }}$ largest industrial enzyme in the world due to their widespread use in diverse biological processing. These enzymes also used for recycling of paper, in the production of juices as washing enzymes and feed additives in food industry [22]. Microbial xylanases are widely used in the diverse biological process including production of animal feed, baked goods, biofuels, food products, feed and bleaching, as well as in the pulp and paper industry [23]. Microbes are some of the preferred sources of xylanases in industry because they offer many benefits. Lipases are extracellular enzymes produced by archaea, bacteria, yeast/molds, protozoa and other extremophilic microbiomes. The extracellular secretion of lipases is well established in diverse groups of fungal communities, mainly in Zygomycetes and Hyphomycetes [24, 25]. Microbial lipases are of marketable importance because of their wider availability from diverse groups of microbiomes, greater stability at diverse environmental conditions, and lower production costs as lipases obtained from animal and plant origins. Phytases produced by extremophilic microbiomes are a class of phosphatase that can release at least one phosphate from phytate at different environmental conditions $[26,27]$. Extracellular phytate degrading enzymes produced by diverse groups of extremophilic microbiomes such as archaea, molds/yeasts, and bacteria have been reported worldwide [28].

The tiny organism of soil and diverse extreme habitats have several functional annotations like nutrients cycling and their fixation, mineralization and solubilization, alleviation of biotic caused by pest-insects, microbial pathogens as well as abiotic stresses by harsh environmental conditions, degradation of polluting elements in the environment [29, 30]. These soil microbes have also a have ability to alleviate various types of stresses of the environment i.e. biotic and abiotic. In biotic stresses alleviation, soil microbes used to control the different types biological pathogens growth like insects, bacteria and fungi by releasing various types of antibiotics and hydrogen cyanide, competing with the nutrients availability [31]. Whereas, in abiotic stress, soil microbiomes undergoes mechanism like release of ACC deaminase, reactive oxygen species by which various types of abiotic stress can be alleviated such cold stress, temperature stress, water stress weather flooding conditions or rain fed conditions, salt stress in the soil and available heavy metals.

Extremophilic microbiomes play a vital role in the circulation of the plant nutrients. These microbes as bio-inoculants are being used across the world to improve yield and nutrient status of agro-ecological ecosystems. The beneficial plantmicrobe associations signify a promising sustainable finding to enhance productivity and reduce the diverse chemical fertilizers used [32]. On earth, various types of stresses like drought, temperature extremes like cold and hot, salinity, heavy metals and water flooding exists, which result reduction of plant growth and substantial decrease in crop yield and productivity [33]. Biotic stress is stress caused by micro and macro-pathogens such as bacteria, yeast/molds, virus, nematodes, insects, and weeds on plants. This stress usually contributes to huge economic losses caused of cash crops, due to this it is considered as a major subject of agricultural research. Abiotic stress is the stress created by adverse climatic conditions that also restrict the crop productivity. In nature, stress is a combined effect of multiple functioning unity rather than single incident [34].

Low and high temperature are the diverse abiotic stresses. Among these and other stresses low temperature is considered as a major limiting factor as $20 \%$ of earth surface is filled with frozen soil, frozen soils (permafrost), glaciers and snow that adversely affects productivity of agricultural products. In agricultural sector, drought is one of the major problems [35]. In which crop productivity are greatly affected in the whole world of drought regions. Microbes are playing important role to controlling this stress as well once they have been isolated and thoroughly studied about their functionalities, such as their ability to withstand extremities and their genetic diversity, and methods are created for their use in farming. Therefore, inoculating plants with multifarious PGP microbiomes also would help to resolve drought in arid regions. Water flooding stress is the another abiotic stress which also an agricultural product destroyer factor. Generally, This stress mainly exists in rice producing fields areas, as every years one- fourth of the worlds rice land are inundated with volatile flash floods that now a day's arise a few times a year's [36].

To survive the plants need oxygen $\left(\mathrm{O}_{2}\right)$, but extreme flooding decreases the amount of $\mathrm{O}_{2}$ in the soil. Lower level of $\mathrm{O}_{2}$ can limited the aerobic restoration. Water flooding also induced the accumulation of ethylene and, depending upon the light condition of submerged plants organs, raises the $\mathrm{CO}_{2}$ concentration. Salinity is the key cause of environments stress that decreases agricultural, area yield and quality of the crops. Salinity has affected and depleted $20 \%$ of the earth's agricultural land i.e. $\sim 45$ million ha. The soil salinity rate is estimated to be $30 \%$ of the global agricultural lands [37]. Salinity is worst in the arid and semi-arid regions that cause osmotic stress, which also decreases 
the growth and productivity of crops [38]. Stalinization usually occurs in two different ways i.e. natural causes and the secondary type is the result of human activity for agricultural production. According to the standard of the US department of agriculture, soil has an electrical conductivity of $\mathrm{ds}^{\mathrm{m}-1}$ or higher can be classified as saline soil. Many studies has suggested that stress of salt as the main cause of the creation of drought-like condition due to water shortages, the creation of the payment of higher ionic content in plants, there by disrupting the usual physiological pathways and the lack of the other nutrients of soil due to high concentration of salt [39].

The industrial revolution and anthropogenic actions, has resulted in drastic increase of heavy metals and radionuclide's in the soil. The environment is continuously threatened by the use of persistent organic pollutants. Bioremediation is the method by which microbes interact with pollutant and degrade it [11, 21]. Microbes are cosmopolitan in their distribution and play a very important role in xenobiotic bioremediation [40]. Pollution remediation is also one of the functional abilities of the soil that helps in converting hazardous compounds in to less toxic compounds that can be degradable in the soil [41]. The bioremediation of aromatic pollutants like phthalate isomers, naphthalene, phenanthrene, benzopyrene is done by microbes mainly Acidovorax, Arthrobacter, Brevibacterium, Polaromonas, Mycobacterium, Rhodococcus, and Sphingomonas [30, 42, 43].

In conclusion, agro-industrially important bioactive compounds and extremozymes from stress-adaptive microbes have been in great demand in agriculture and different industry. The biodiversity of stress-adaptive microbiomes (acidophilic, alkaliphilic, halophilic, metallotolerant, piezophilic, psychophilic, psychrotolerant, radiation-resistant, thermophilic, hyperthermophilic, toxotolerant and xerophilic) and extremozymes produced by extremophilic microbiomes have very diverse possible applications in various fields such as including food industries, agricultural industries, pharmaceutical industry, chemical industry, detergent industry, and leather industry. The area of application of extremozymes for biotechnological purposes is expanding over time. Looking up to the abilities and applications of soil microbes in the agriculture and environments, it can be concluded that these tiny-miracles can be utilized in the environment and agriculture field. The extremophilic microbiomes i.e stress-adaptive microorganisms are ever-present in nature and have been sorted from all the extreme habitats studies. The microbes from soil and air are useful for different processes in plant and ecosystems. The soil microbiomes have capability to nutrient acquisitions in plants for agro-environmental sustainability. In future also, these microbes can also replace the chemical based products, which will be support the sustainability and make earth more clean and green i.e. pollution free environment.

\section{ACKNOWLEDGEMENTS}

The authors is grateful to the Department of Biotechnology, Dr. Khem Singh Gill Akal College of Agriculture, Eternal University, Baru Sahib and Department of Environment, Science and Technology (DEST), Shimla funded project "Development of microbial consortium as bioinoculants for drought and low temperature growing crops for organic farming in Himachal Pradesh" for providing the facilities and financial support.

\section{CONFLICTS OF INTEREST}

There are no conflicts of interest.

\section{REFERENCES}

1. Yadav AN, Verma P, Kumar M, Pal KK, Dey R, Gupta A, Padaria JC, Gujar GT, Kumar S, Suman A et al. Diversity and phylogenetic profiling of niche-specific Bacilli from extreme environments of India. Ann Microbiol. 2015; 65(2):611-629. https://doi.org/10.1007/s13213014-0897-9

2. Saxena AK, Yadav AN, Rajawat M, Kaushik R, Kumar R, Kumar M, Prasanna R, Shukla L. Microbial diversity of extreme regions: An unseen heritage and wealth. Indian J Plant Genet Resour. 2016; 29(3):246-248. https://doi.org/10.5958/0976-1926.2016.00036.X

3. Sahay H, Yadav AN, Singh AK, Singh S, Kaushik R, Saxena AK. Hot springs of Indian Himalayas: Potential sources of microbial diversity and thermostable hydrolytic enzymes. 3 Biotech. 2017; 7(2):1-11. https://doi.org/10.1007/s13205-017-0762-1

4. Hough DW, Danson MJ. Extremozymes. Curr Opin Chem Biol. 1999; 3(1):39-46. https://doi.org/10.1016/S1367-5931(99)80008-8

5. Sarmiento F, Peralta R, Blamey JM. Cold and hot extremozymes: industrial relevance and current trends. Front Bioeng Biotechnol. 2015; 3:148. https://doi.org/10.3389/fbioe.2015.00148

6. Verma P, Yadav AN, Kumar V, Singh DP, Saxena AK: Beneficial plant-microbes interactions: Biodiversity of microbes from diverse extreme environments and its impact for crop improvement. In: PlantMicrobe Interactions in Agro-Ecological Perspectives, Volume 2: Microbial Interactions and Agro-Ecological Impacts. Edited by Singh DP, Singh HB, Prabha R. Singapore: Springer; 2017: 543-580. https://doi.org/10.1007/978-981-10-6593-4_22

7. Yadav AN, Gulati S, Sharma D, Singh RN, Rajawat MVS, Kumar R, Dey R, Pal KK, Kaushik R, Saxena AK. Seasonal variations in culturable archaea and their plant growth promoting attributes to predict their role in establishment of vegetation in Rann of Kutch. Biologia. 2019; 74(8):1031-1043. https://doi.org/10.2478/s11756-019$\underline{00259-2}$

8. Yadav AN, Kour D, Rana KL, Yadav N, Singh B, Chauhan VS, Rastegari AA, Hesham AE-L, Gupta VK: Metabolic Engineering to Synthetic Biology of Secondary Metabolites Production. In: New and Future Developments in Microbial Biotechnology and Bioengineering. Edited by Gupta VK, Pandey A. Amsterdam: Elsevier; 2019: 279-320. https://doi.org/10.1016/B978-0-444-63504-4.00020-7

9. Yadav AN, Sachan SG, Verma P, Saxena AK. Prospecting cold deserts of north western Himalayas for microbial diversity and plant growth promoting attributes. J Biosci Bioeng. 2015; 119(6):683-693. https://doi.org/10.1016/j.jbiosc.2014.11.006

10. Yadav AN, Sachan SG, Verma P, Tyagi SP, Kaushik R, Saxena AK. Culturable diversity and functional annotation of psychrotrophic bacteria from cold desert of Leh Ladakh (India). World J Microbiol Biotechnol. 2015; 31(1):95-108. https://doi.org/10.1007/s11274-014$\underline{1768-\mathrm{Z}}$ 
11. Kumar M, Yadav AN, Saxena R, Rai PK, Paul D, Tomar RS. Novel methanotrophic and methanogenic bacterial communities from diverse ecosystems and their impact on environment. Biocatal Agric Biotechnol. 2021; 33:102005 https://doi.org/10.1016/j.bcab.2021.1020 $\underline{05}$

12. Dumorné K, Córdova DC, Astorga-Eló M, Renganathan P. Extremozymes: a potential source for industrial applications. J Microbiol Biotechnol. 2017; 27(4):649-659. https://doi.org/10.4014/ imb.1611.11006

13. Saxena AK, Padaria JC, Gurjar GT, Yadav AN, Lone SA, Tripathi M, $S$ RMV: Insecticidal formulation of novel strain of Bacillus thuringiensis AK 47. In.: Indian Patent 340541; 2020.

14. Rasmussen RS, Morrissey MT. Marine biotechnology for production of food ingredients. Adv Food Nutr Res. 2007; 52:237-292. https://doi.org/10.1016/S1043-4526(06)52005-4

15. Barcelos MC, Ramos CL, Kuddus M, Rodriguez-Couto S, Srivastava N, Ramteke PW, Mishra PK, Molina G. Enzymatic potential for the valorization of agro-industrial by-products. Biotechnol Lett. 2020:129. https://doi.org/10.1007/s10529-020-02957-3

16. Kumar M, Yadav AN, Saxena R, Paul D, Tomar RS. Biodiversity of pesticides degrading microbial communities and their environmental impact. Biocatal Agric Biotechnolo. 2021; 31:101883. https://doi.org/10.1016/j.bcab.2020.101883

17. Yadav AN. Beneficial plant-microbe interactions for agricultural sustainability. J Appl Biol Biotechnol. 2021; 9(1):1-4.

18. Yadav AN. Microbial biotechnology for bio-prospecting of microbial bioactive compounds and secondary metabolites. J Appl Biol Biotechnol. 2021; 9(2):1-6.

19. Yadav AN, Sachan SG, Verma P, Kaushik R, Saxena AK. Cold active hydrolytic enzymes production by psychrotrophic Bacilli isolated from three sub-glacial lakes of NW Indian Himalayas. J Basic Microbiol. 2016; 56:294-307. https://doi.org/10.1002/jobm.201500230

20. Razzaq A, Shamsi S, Ali A, Ali Q, Sajjad M, Malik A, Ashraf M. Microbial proteases applications. Front Bioeng Biotechnol. 2019; 7:110. https://doi.org/10.3389/fbioe.2019.00110

21. Kour D, Kaur T, Devi R, Yadav A, Singh M, Joshi D, Singh J, Suyal DC, Kumar A, Rajput VD et al. Beneficial microbiomes for bioremediation of diverse contaminated environments for environmental sustainability: present status and future challenges. EnvironSci Poll Res. 2021. https://doi.org/10.1007/s11356-021-132527 https://doi.org/10.1007/s11356-021-13252-7

22. Bhat M. Cellulases and related enzymes in biotechnology. Biotechnol Adv. 2000; 18(5):355-383. https://doi.org/10.1016/S07349750(00)00041-0

23. Kumar V, Shukla P: Functional aspects of xylanases toward industrial applications. In: Frontier discoveries and innovations in interdisciplinary microbiology. Springer; 2016: 157-165. https://doi.org/ 10.1007/978-81-322-2610-9 9

24. Yadav AN, Kumar R, Kumar S, Kumar V, Sugitha T, Singh B, Chauhan V, Dhaliwal HS, Saxena AK. Beneficial microbiomes: biodiversity and potential biotechnological applications for sustainable agriculture and human health. J Appl Biol Biotechnol. 2017; 5(6):4557.

25. Devi R, Kaur T, Kour D, Rana KL, Yadav A, Yadav AN. Beneficial fungal communities from different habitats and their roles in plant growth promotion and soil health. Microb Biosys. 2020; 5(1):21-47. https://doi.org/10.21608/mb.2020.32802.1016

26. Singh B, Boukhris I, Pragya, Kumar V, Yadav AN, FarhatKhemakhem A, Kumar A, Singh D, Blibech M, Chouayekh H et al. Contribution of microbial phytases to the improvement of plant growth and nutrition: A review. Pedosphere. 2020; 30(3):295-313. https://doi.org/10.1016/S1002-0160(20)60010-8

27. Kumar V, Yadav AN, Verma P, Sangwan P, Saxena A, Kumar K, Singh B. $\beta$-Propeller phytases: Diversity, catalytic attributes, current developments and potential biotechnological applications. Int J Biol Macromolec. 2017; 98:595-609. https://doi.org/10.1016/j.ijbiomac. 2017.01.134
28. Yadav AN: Soil Microbiomes for Sustainable Agriculture, Vol2:Functional Annotation. In. Cham: Springer; 2021.

29. Singh A, Kumar R, Yadav AN, Mishra S, Sachan S, Sachan SG: Tiny microbes, big yields: Microorganisms for enhancing food crop production sustainable development. In: Trends of Microbial Biotechnology for Sustainable Agriculture and Biomedicine Systems: Diversity and Functional Perspectives. Edited by Rastegari AA, Yadav AN, Yadav N. Amsterdam: Elsevier; 2020: 1-15. https://doi.org/10.1016/B978-0-12-820526-6.00001-4

30. Sharaff MS, Subrahmanyam G, Kumar A, Yadav AN: Mechanistic understanding of root-microbiome interaction for sustainable agriculture in polluted soils. In: Trends of Microbial Biotechnology for Sustainable Agriculture and Biomedicine Systems: Diversity and Functional Perspectives. Edited by Rastegari AA, Yadav AN, Yadav N. Amsterdam: Elsevier; 2020: 61-84. https://doi.org/10.1016/B9780-12-820526-6.00005-1

31. Gómez Expósito R, De Bruijn I, Postma J, Raaijmakers JM. Current insights into the role of rhizosphere bacteria in disease suppressive soils. Front Microbiol. 2017; 8:2529. https://doi.org/10.3389/ fmicb.2017.02529

32. Kour D, Kaur T, Devi R, Rana KL, Yadav N, Rastegari AA, Yadav AN: Biotechnological applications of beneficial microbiomes for evergreen agriculture and human health. In: Trends of Microbial Biotechnology for Sustainable Agriculture and Biomedicine Systems: Perspectives for Human Health. Edited by Rastegari AA, Yadav AN, Yadav N. Amsterdam: Elsevier; 2020: 255-279. https://doi.org/ $\underline{10.1016 / \mathrm{B} 978-0-12-820528-0.00019-3}$

33. Ramegowda V, Senthil-Kumar M. The interactive effects of simultaneous biotic and abiotic stresses on plants: mechanistic understanding from drought and pathogen combination. J Plant Physiol. 2015; 176:47-54. https://doi.org/10.1016/j.jplph.2014.11.008

34. Mahajan S, Tuteja N. Cold, salinity and drought stresses: an overview. Arch Biochem Biophys. 2005; 444(2):139-158. https://doi.org/10.1016/j.abb.2005.10.018

35. Malyan SK, Kumar A, Kumar J, Smita Kumar S. Water management tool in rice to combat two major environmental issues: global warming and water scarcity. Environmental concerns of 21st century: Indian and global context Book Age publication, New Delhi. 2016:46-58.

36. Mackill D, Ismail A, Singh U, Labios R, Paris T: Development and rapid adoption of submergence-tolerant (Sub1) rice varieties. In: Advances in agronomy. vol. 115: Elsevier; 2012: 299-352. https://doi.org/10.1016/B978-0-12-394276-0.00006-8

37. Shrivastava P, Kumar R. Soil salinity: a serious environmental issue and plant growth promoting bacteria as one of the tools for its alleviation. Saudi J Biol Sci. 2015; 22(2):123-131. https://doi.org/10.1016/j.sjbs.2014.12.001

38. Yadav AN, Saxena AK. Biodiversity and biotechnological applications of halophilic microbes for sustainable agriculture. J Appl Biol Biotechnol. 2018; 6(1):48-55.

39. Vaishnav A, Kumari S, Jain S, Varma A, Tuteja N, Choudhary DK. PGPR-mediated expression of salt tolerance gene in soybean through volatiles under sodium nitroprusside. J Basic Microbiol. 2016; 56(11):1274-1288. https://doi.org/10.1002/jobm.201600188

40. Panigrahi S, Velraj P, Rao TS: Functional microbial diversity in contaminated environment and application in bioremediation. In: Microbial Diversity in the Genomic Era. Elsevier; 2019: 359-385. https://doi.org/10.1016/B978-0-12-814849-5.00021-6

41. Kushwaha A, Hans N, Kumar S, Rani R. A critical review on speciation, mobilization and toxicity of lead in soil-microbe-plant system and bioremediation strategies. Ecotoxicol Environ Saf. 2018; 147:1035-1045. https://doi.org/10.1016/j.ecoenv.2017.09.049

42. Seo J-S, Keum Y-S, Li QX. Bacterial degradation of aromatic compounds. Int J Environ Res Public Health. 2009; 6(1):278-309. https://doi.org/10.3390/ijerph6010278

43. Phale PS, Sharma A, Gautam K: Microbial degradation of xenobiotics like aromatic pollutants from the terrestrial environments. In: Pharmaceuticals and Personal Care Products: 
Waste Management and Treatment Technology. Elsevier; 2019: 259-

278. https://doi.org/10.1016/B978-0-12-816189-0.00011-1

44. Kour D, Rana KL, Kaur T, Singh B, Chauhan VS, Kumar A, Rastegari AA, Yadav N, Yadav AN, Gupta VK: Extremophiles for Hydrolytic Enzymes Productions: Biodiversity and Potential Biotechnological Applications. In: Bioprocessing for Biomolecules Production. Edited by Molina G, Gupta VK, Singh B, Gathergood N; 2019: 321-372. https://doi.org/10.1002/9781119434436.ch16

45. Kumar M, Yadav AN, Saxena R, Paul D, Tomar RS. Biodiversity of pesticides degrading microbial communities and their environmental impact. Biocatal Agri Biotech. 2021; 31:101883.

\section{How to cite this article:}

Yadav AN. Biodiversity and bioprospecting of extremephilic microbiomes for agro-environmental sustainability. J App Biol Biotech. 2021;9(3):1-6. DOI: $10.7324 / \mathrm{JABB} .2021 .9301$ 